\title{
Correction to: Broadcasting a file in a communication network
}

\author{
Kai-Simon Goetzmann ${ }^{1}$ - Tobias Harks ${ }^{3} \cdot$ Max Klimm² $^{2}$
}

Accepted: 24 November 2021 / Published online: 16 February 2022

(c) The Author(s) 2022

\section{Correction to: Journal of Scheduling (2020) 23:211-232 https://doi.org/10.1007/s10951-020-00643-w}

The article "Broadcasting a file in a communication network", written by Kai-Simon Goetzmann, Tobias Harks and Max Klimm, was originally published electronically on the publisher's internet portal on 11 February 2020 without open access. With the author(s)' decision to opt for Open Choice, the copyright of the article changed on 27 October 2021 to () The Author(s) 2021 and the article is forthwith distributed under a Creative Commons Attribution 4.0 International License, which permits use, sharing, adaptation, distribution and reproduction in any medium or format, as long as you give appropriate credit to the original author(s) and the source, provide a link to the Creative Commons licence and indicate if changes were made. The images or other third-party material in this article is included in the article's Creative Commons licence, unless indicated otherwise in a credit line to the material. If material is not included in the article's Creative Commons licence and your intended use is not permitted by statutory regulation or exceeds the permitted use, you will need to obtain permission directly from the copyright holder. To view a copy of this licence, visit http:// creativecommons.org/licenses/by/4.0.

Open Access This article is licensed under a Creative Commons Attribution 4.0 International License, which permits use, sharing, adaptation, distribution and reproduction in any medium or format, as long as you give appropriate credit to the original author(s) and the source, provide a link to the Creative Commons licence, and indicate if changes were made. The images or other third party material in this article are included in the article's Creative Commons licence, unless indicated otherwise in a credit line to the material. If material is not included in the article's Creative Commons licence and your intended use is not permitted by statutory regulation or exceeds the permitted use, you will need to obtain permission directly from the copyright holder. To view a copy of this licence, visit http://creativecomm ons.org/licenses/by/4.0/.

Publisher's Note Springer Nature remains neutral with regard to jurisdictional claims in published maps and institutional affiliations.
The original article can be found online at https://doi.org/10.1007/ s10951-020-00643-w.

\section{Max Klimm}

max.klimm@hu-berlin.de

Tobias Harks

tobias.harks@math.uni-augsburg.de

1 Institut für Mathematik, Technische Universität Berlin, Straße des 17. Juni 136, 10623 Berlin, Germany

2 School of Business and Economics, Humboldt-Universität zu Berlin, Spandauer Straße 1, 10178 Berlin, Germany

3 Institut für Mathematik, Universität Augsburg, 86135 Augsburg, Germany 